\title{
Article \\ Oxidative DNA Damage and Cisplatin Neurotoxicity Is Exacerbated by Inhibition of OGG1 Glycosylase Activity and APE1 Endonuclease Activity in Sensory Neurons
}

\author{
Adib Behrouzi ${ }^{1} \mathbb{D}$, Hanyu Xia ${ }^{1}$, Eric L. Thompson ${ }^{1}$, Mark R. Kelley ${ }^{1,2} \mathbb{D}$ and Jill C. Fehrenbacher ${ }^{3, *(D)}$ \\ 1 Department of Pharmacology and Toxicology, Indiana University School of Medicine, Indianapolis, IN 46202, USA; \\ abehrouz@iu.edu (A.B.); xiah@iu.edu (H.X.); elthomps@iupui.edu (E.L.T.); mkelley@iu.edu (M.R.K.) \\ 2 Department of Pediatrics, Indiana University Simon Comprehensive Cancer Center, Indiana University \\ School of Medicine, Indianapolis, IN 46202, USA \\ 3 Department of Pharmacology and Toxicology, Stark Neuroscience Research Institute, Indiana University \\ Simon Comprehensive Cancer Center, Indiana University School of Medicine, Indianapolis, IN 46202, USA \\ * Correspondence: jfehrenb@iu.edu; Tel.: +1-317-274-8360
}

Citation: Behrouzi, A.; Xia, H.; Thompson, E.L.; Kelley, M.R.; Fehrenbacher, J.C. Oxidative DNA Damage and Cisplatin Neurotoxicity Is Exacerbated by Inhibition of OGG1 Glycosylase Activity and APE1 Endonuclease Activity in Sensory Neurons. Int. J. Mol. Sci. 2022, 23 , 1909. https://doi.org/10.3390/ ijms23031909

Academic Editor: David M. Wilson III

Received: 29 December 2021

Accepted: 3 February 2022

Published: 8 February 2022

Publisher's Note: MDPI stays neutral with regard to jurisdictional claims in published maps and institutional affiliations.

Copyright: (C) 2022 by the authors. Licensee MDPI, Basel, Switzerland. This article is an open access article distributed under the terms and conditions of the Creative Commons Attribution (CC BY) license (https:// creativecommons.org/licenses/by/ $4.0 /)$.

\begin{abstract}
Cisplatin can induce peripheral neuropathy, which is a common complication of anticancer treatment and negatively impacts cancer survivors during and after completion of treatment; therefore, the mechanisms by which cisplatin alters sensory neuronal function to elicit neuropathy are the subject of much investigation. Our previous work suggests that the DNA repair activity of APE1/Ref-1, the rate-limiting enzyme of the base excision repair (BER) pathway, is critical for neuroprotection against cisplatin. A specific role for 8-oxoguanine DNA glycosylase-1 (OGG1), the glycosylase that removes the most common oxidative DNA lesion, and putative coordination of OGG1 with APE1/Ref-1 in sensory neurons, has not been investigated. We investigated whether inhibiting OGG1 glycosylase activity with the small molecule inhibitor, TH5487, and/or APE1/Ref-1 endonuclease activity with APE Repair Inhibitor III would alter the neurotoxic effects of cisplatin in sensory neuronal cultures. Sensory neuron function was assessed by calcitonin gene-related peptide (CGRP) release, as a marker of sensitivity and by neurite outgrowth. Cisplatin altered neuropeptide release in an inverse U-shaped fashion, with low concentrations enhancing and higher concentrations diminishing CGRP release. Pretreatment with BER inhibitors exacerbated the functional effects of cisplatin and enhanced 8oxo-dG and adduct lesions in the presence of cisplatin. Our studies demonstrate that inhibition of OGG1 and APE1 endonuclease activity enhances oxidative DNA damage and exacerbates neurotoxicity, thus limiting oxidative DNA damage in sensory neurons that might alleviate cisplatin-induced neuropathy.
\end{abstract}

Keywords: cisplatin; DNA damage; oxidative stress; chemotherapy-induced peripheral neuropathy; sensory neuron; neuropeptide; neurite outgrowth; base excision repair

\section{Introduction}

Chemotherapy-induced peripheral neuropathy (CIPN) is a very common ailment of cancer patients and survivors [1] and is defined by the presence of one or more of the following symptoms starting in the hands and feet: dysesthesia, numbness, sharp stabbing or burning pain, hypersensitivity to cold, and loss of reflexes. Cisplatin is a chemotherapeutic commonly used for the treatment of many cancers, including testicular, bladder, ovarian, head and neck, lung, and cervical cancers [2], and causes some of the most severe neuropathy. This neuropathy can result in patients withdrawing from their treatment schedules and disrupting the treatment of their cancer.

The mechanisms by which cisplatin alters sensory neuronal function to result in neuropathy are the subject of much investigation. Preclinical studies have suggested that mitochondrial toxicity [3-5], changes in calcium handling [6], oxidative stress [6,7], DNA 
damage [7-9], and morphological changes [9,10] all occur in sensory neurons secondary to cisplatin exposure. Cisplatin contains a central platinum ion, which allows for the drug to cross-link DNA and thereby inhibit cellular replication [11] in cancer cells. In addition to DNA adducts induced by cisplatin, the drug also increases oxidative stress with increases in reactive oxygen species (ROS) [12] and subsequent oxidative DNA damage $[13,14]$ to further inhibit cellular replication. Even though sensory neurons are unaffected by the inhibition of replication due to their post-mitotic status, DNA damage can still affect function through changes in gene transcription [15] and intracellular signaling pathways activated in response to DNA damage and the cognate processes engaged to repair DNA lesions.

The base excision repair (BER) pathway is primarily responsible for repairing nonbulky DNA damage, such as oxidative and alkylation DNA damage. Because of the low oxidation potential for guanines, the most prevalent DNA lesion induced by reactive oxygen species is 7,8-dihydro-8-oxo-2'-deoxyguanosine (8oxo-dG) [16-18]. The first step of BER is to recognize and remove the damaged base, 8-oxodG, and is mediated by 8-oxoguanine DNA glycosylase-1 (OGG1) [19]. Removal of the base generates an apurinic/apyrimidinic (AP) site, which is then recognized and processed by the multifunctional AP endonuclease $1 /$ Ref-1 (APE1/Ref-1), which cleaves the DNA backbone, allowing DNA polymerase $\beta$ $(\operatorname{Pol} \beta)$ to insert the missing base through template-directed synthesis [20]. We previously demonstrated that APE1/Ref-1 knockdown exacerbates the neuronal effects of cisplatin and that overexpression of APE1/Ref- 1 rescues the neurons $[7,21,22]$, suggesting that oxidative DNA damage mediates, at least in part, the deleterious effects of cisplatin on neuronal function. Oxidative DNA lesions, such as 8oxo-dG, near cisplatin-DNA cross links might also interrupt cross-link lesion repair, increasing any impact of the oxidative damage alone [23].

What is still unknown are the mechanisms by which oxidative DNA damage alters neuronal function. Work in cancer cells has demonstrated that the presence of oxidative DNA lesions alone can alter gene transcription [24-27]; however, additional work has shown that the binding of enzymes critical for BER can also elicit changes in transcription that could have variable effects on gene transcription [28,29]. Indeed, inhibition of OGG1 glycosylase activity by the small molecule, TH5487, prevents inflammatory gene expression changes induced by cellular exposure to TNF $\alpha$ [28].

In these studies, we expand on our previous findings to identify the relative roles of the major glycosylase required for 8oxo-dG lesion removal, OGG1, and APE1/Ref-1 on mitigating the damage to sensory neurons induced by cisplatin. We determined that inhibiting the activity of either OGG1 or APE1/Ref-1 increases 8-oxodG levels in neuronal cultures and that this increase is exacerbated by cisplatin. Functionally, cisplatin has variable effects on sensory neuron function, with increases in neuropeptide release at low concentrations, and a diminution of release at higher concentrations. Inhibition of the BER enzymes appears to exacerbate the effects of cisplatin to facilitate the desensitization of neuropeptide release from sensory neurons. These data support a role for oxidative DNA damage, and specifically 8oxo-dG formation, as a mediator of cisplatin-induced neurotoxicity.

\section{Results}

2.1. Inhibition of Either OGG1 Glycosylase Activity or APE1 DNA Repair Activity Diminishes the Sensitizing Effects of Cisplatin on Neuropeptide Release

Cellular exposure to cisplatin causes the formation of platin-DNA crosslinks and the generation of ROS [22,30-32], producing oxidative DNA damage that is primarily repaired by the BER pathway [33]. Left unrepaired, oxidative DNA damage contributes to neuronal toxicity induced by cisplatin, as determined by experiments in which APE1 expression or activity was modulated $[7,21,22]$. The desire to more completely understand the base excision pathway and the contribution of each step of the pathway to alterations in neuronal function led us to examine the effects of inhibiting OGG1 glycosylase activity and/or APE1 DNA repair activity. 
Before we could examine the effects of BER inhibitors, we needed to establish the effects of increasing concentrations of cisplatin on CGRP release and content, as cisplatin and other chemotherapeutics have demonstrated an inverse U-shaped effect on release, with low concentrations of the drug enhancing the stimulated release of the peptide and higher concentrations diminishing the release of the peptide [34]. Therefore, we treated neuronal cultures with increasing concentrations of cisplatin, using dd water as a vehicle, for $24 \mathrm{~h}$ prior to a release experiment. As illustrated in Figure 1A, cisplatin significantly enhanced the stimulated release of CGRP at a concentration of $30 \mu \mathrm{M}$ from $32.4 \pm 2.0$ to $59.8 \pm 9.7 \mathrm{fmol} /$ well $/ 10 \mathrm{~min}$; however, increasing the concentration of cisplatin further resulted in a drop in the stimulated release of CGRP. Figure 1B demonstrates that treated sensory neuron cultures with high concentrations of cisplatin $(100 \mu \mathrm{M})$ diminishes the neuropeptide content from $469.8 \pm 76.6$ to $255.3 \pm 32.37 \mathrm{fmol} /$ well; however, no significant effect of a $30 \mu \mathrm{M}$ cisplatin treatment on CGRP content was observed.

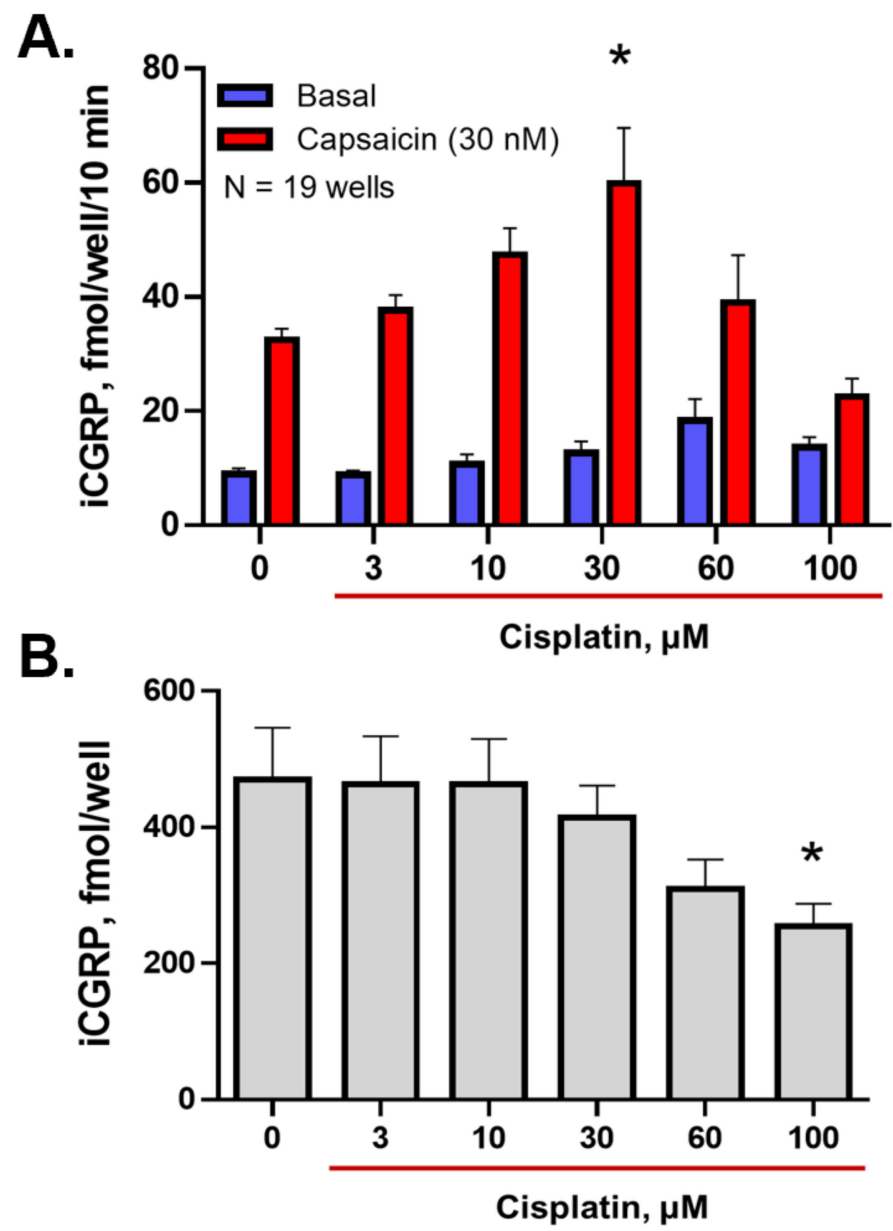

Figure 1. CGRP release from neuronal cultures is altered following exposure to cisplatin. (A). Columns represent the mean \pm SEM of CGRP release stimulated by a $10 \mathrm{~min}$ exposure to $30 \mathrm{nM}$ capsaicin following a $24 \mathrm{~h}$ exposure to increasing concentrations of cisplatin $(30 \mu \mathrm{M}) .{ }^{*} p<0.0001$ comparing stimulated release in CIS to no treatment control, two-way ANOVA with Tukey's posttest. (B). Each column represents the mean \pm SEM of the total CGRP content following exposure to cisplatin treatments. ${ }^{*} p<0.05$ comparing content in CIS $(100 \mu \mathrm{M})$ to no treatment control, one-way ANOVA with Dunnett's posttest.

To examine how inhibition of OGG1 and APE1 alters the effects of cisplatin, we exposed neuronal cultures to TH5487 $(3 \mu \mathrm{M})$, ARI3 $(10 \mu \mathrm{M})$, a combination of the drugs, or to vehicle controls for $48 \mathrm{~h}$ and then added vehicle or cisplatin $(30 \mu \mathrm{M})$ for the last $24 \mathrm{~h}$ in culture prior to the experiment examining basal- and capsaicin-stimulated release 
of the putative nociceptive neuropeptide, CGRP. As illustrated in Figure 2A, exposure to capsaicin (bars in red) stimulates the release of CGRP. Exposure of the cultures to cisplatin elicits a sensitization of that stimulated release from an average of $27.2 \pm 6.3$ to $67.4 \pm 10.3 \mathrm{fmol} /$ well $/ 10 \mathrm{~min}$. Pretreatment with either BER inhibitor alone attenuated the increase in release elicited by cisplatin and combining the inhibitors trended towards an additive effect; however, the effects of combination were not significant. The changes in release of CGRP were not secondary to an altered content of CGRP in the neurons, as the total content of CGRP was similar in cultures treated with BER inhibitors in the absence and presence of cisplatin (Figure 2B).

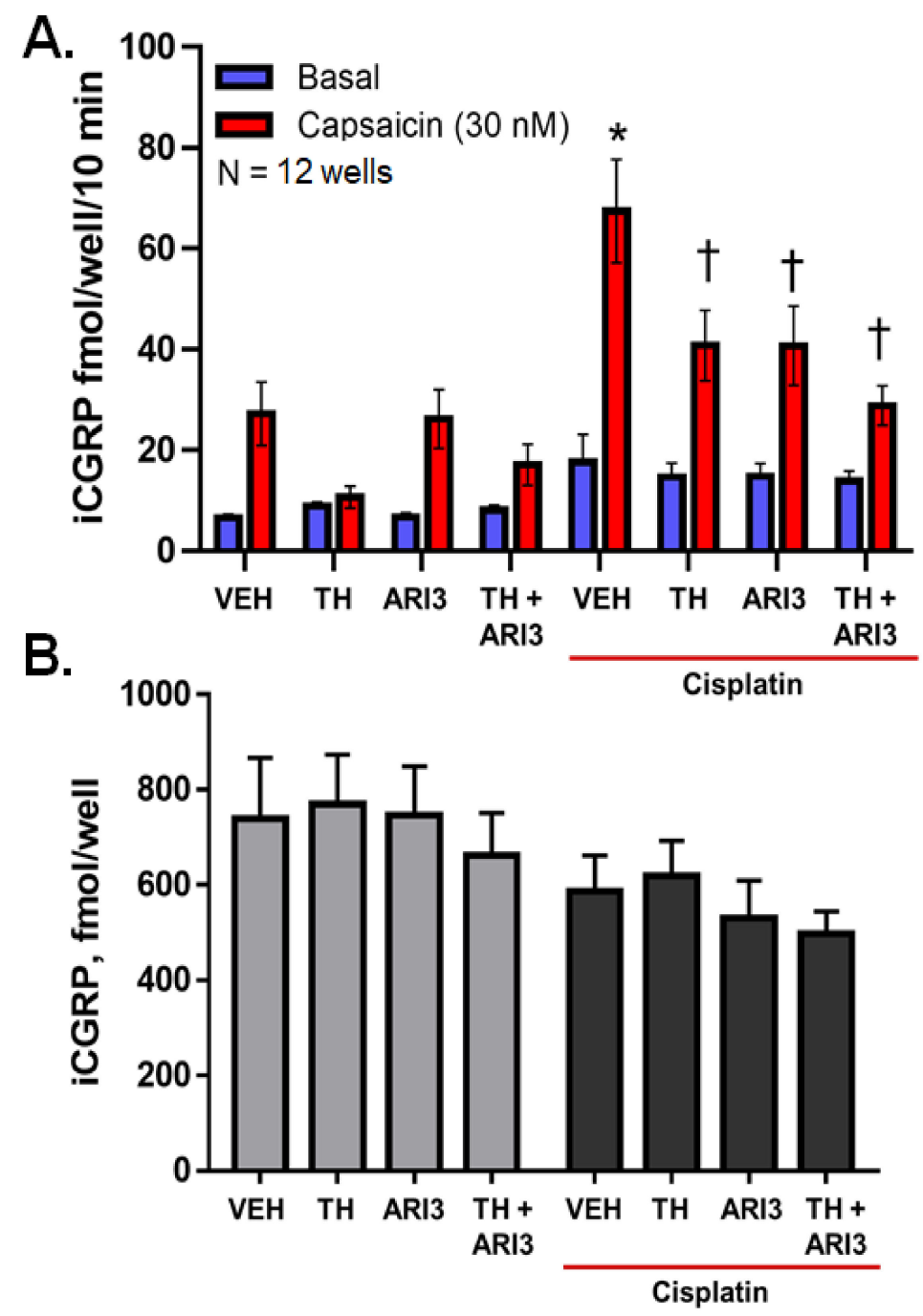

Figure 2. CGRP release from neuronal cultures is altered following exposure to cisplatin and the changes in stimulated CGRP release following exposure to base excision repair inhibitors. (A). Columns represent the mean \pm SEM of CGRP release stimulated by a $10 \mathrm{~min}$ exposure to $30 \mathrm{nM}$ capsaicin following a $24 \mathrm{~h}$ exposure to cisplatin $(30 \mu \mathrm{M}) .{ }^{*} p<0.0001$ comparing stimulated release in CIS to VEH controls; $\uparrow p<0.001$ comparing CIS effects in the presence and absence of base excision repair inhibitors, two-way ANOVA with Tukey's posttest. (B). Each column represents the mean \pm SEM of the total CGRP content following the indicated treatments.

\subsection{Inhibition of Either OGG1 Glycosylase Activity or APE1 DNA Repair Activity Enhances} Basal Levels of 8oxo-dG Lesions and This Effect Is Exacerbated by Cisplatin Treatment

The importance of DNA repair pathways to maintain the integrity of DNA in postmitotic cells, such as neurons, has been highlighted recently. The platin drugs have the potential to create oxidative lesions and adducts within DNA and RNA and the base and 
nucleotide excision repair pathways, respectively, are thought to eliminate that damage. We investigated the effects of a $48 \mathrm{~h}$ pretreatment with BER inhibitors on 80xo-dG levels in neuronal cultures in the absence and presence of a $6 \mathrm{~h}$ exposure to cisplatin. The images in Figure 3A depict representative micrographs of 8oxo-dG immunoreactivity in sensory neuron cultures. To limit the 8oxo-dG signal to sensory neurons, we utilized a PGP9.5 mask during the image analysis, so that only those nuclei in close proximity to sensory neurons were assessed. The quantification of $80 x \mathrm{o}-\mathrm{dG}$ is depicted in Figure 3B. As we expected, inhibiting OGG1 or APE1 resulted in an increase in 8oxo-dG levels from a basal level of $21.1 \pm 0.7$ to $30.4 \pm 0.7$ and $30.7 \pm 0.9$ relative fluorescence units (RFU), respectively, even in the absence of cisplatin treatment, suggesting that there is a basal level of oxidative damage within the neurons that is constantly being repaired via the enzymes in the BER pathway. Surprisingly, we did not observe an increase in 8oxo-dG levels in cultures treated with cisplatin; however, we did see an exacerbation of damage in the inhibitor-treated cells treated with cisplatin, as 8oxo-dG levels increased to $36.8 \pm 0.4$ and $36.9 \pm 0.7$ RFU in the presence of TH and ARI3, respectively, compared with treatment in the absence of cisplatin.

\section{A}
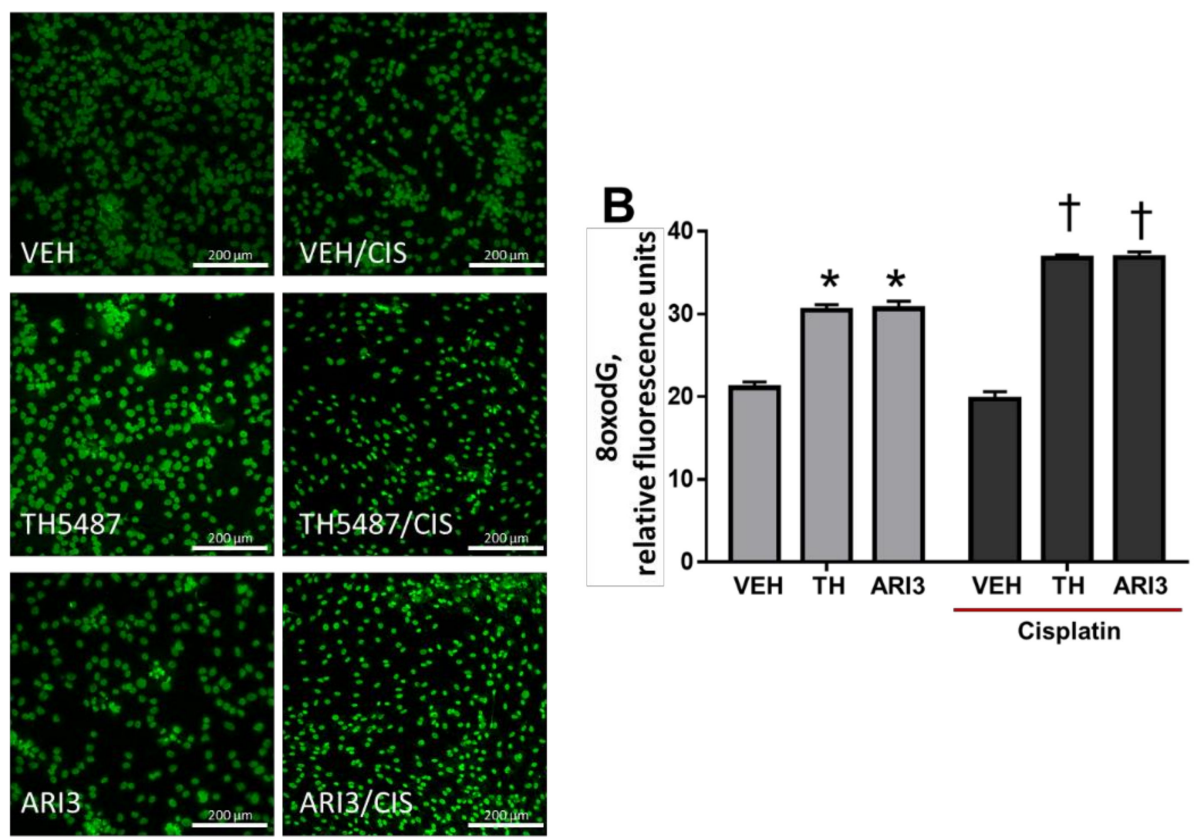

Figure 3. Effects of cisplatin and base excision repair inhibitors on 8-oxodG levels in cells adjacent to sensory neurons. (A), Representative immunostaining for 8-oxodG (green) in sensory neuron cultures. The original magnification was $\times 20$. Scale bar represents $200 \mu \mathrm{m}$. (B), Quantitative analysis of the integrated density of 8-oxodG staining within PGP9.5+ regions of the image field, acquired as relative fluorescence units using Cytation5 software. ${ }^{*} p<0.0001$ comparing TH and ARI3 to $\mathrm{VEH} ;+p<0.0001$ comparing TH/CIS and ARI3/CIS to inhibitors alone, two-way ANOVA with Tukey's posttest.

\subsection{Inhibition of APE1 DNA Repair Activity Enhances Cisplatin Adduct Levels in Neuronal Cultures}

Although the focus of these studies is on oxidative DNA damage and the base excision repair pathway, the most recognized neuronal DNA damage elicited by cisplatin is that of adduct formation $[35,36]$. We previously demonstrated that diminishing the expression of APE1 increased the presence of cisplatin adducts, suggesting possible crosstalk between APE1 and the NER pathway [37]. To ascertain whether pharmacological inhibition of OGG1 or APE1 alters levels of cisplatin adducts, we pretreated neuronal cultures with BER inhibitors for $48 \mathrm{~h}$ in the absence and presence of a $6 \mathrm{~h}$ exposure to cisplatin and then measured adducts. The images in Figure 4A depict representative micrographs of cisplatin adduct immunoreactivity in sensory neuron cultures. To limit the adduct signal to sensory neurons, we utilized a PGP9.5 mask during the image analysis, so that only 
those nuclei in close proximity to sensory neurons were assessed. The quantification of cisplatin adducts is depicted in Figure 4B. There was some background staining for cisplatin adducts in all conditions; however, we did not observe an expected increase in cisplatin adducts in the absence of BER inhibitors. We did see a significant increase in cisplatin adducts with treatment of either of the BER inhibitors compared with background levels in vehicle-treated cultures. Furthermore, inhibition of APE1 dramatically increased the levels of cisplatin adducts from a background level of $46.2 \pm 1.7$ with cisplatin alone to $95.7 \pm 2.3$ RFU with ARI3 pretreatment combined with cisplatin treatment.

A
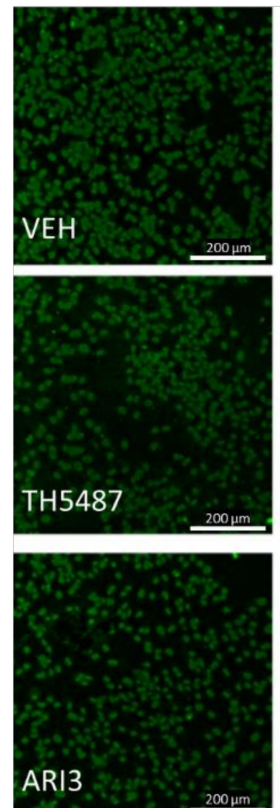
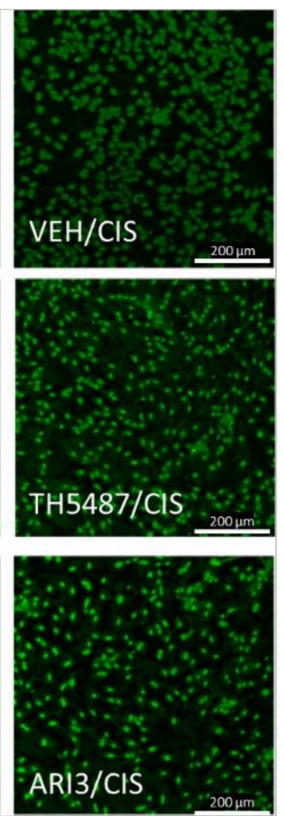

B

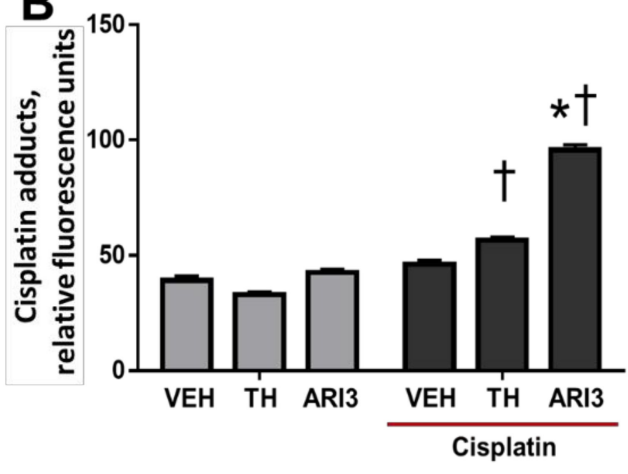

Figure 4. Effects of cisplatin and base excision repair inhibitors on cisplatin adduct levels in cells adjacent to sensory neurons. (A) Representative immunostaining for cisplatin adducts (green) in sensory neuron cultures. The original magnification was $\times 20$. Scale bar represents $200 \mu \mathrm{m}$. (B) Quantitative analysis of the integrated density of adduct staining within PGP9.5+ regions of the image field, acquired as relative fluorescence units using Cytation 5 software. $+p<0.0001$ comparing $\mathrm{TH} / \mathrm{CIS}$ and ARI3/CIS to TH/VEH and ARI3/VEH, respectively, ${ }^{*} p<0.0001$ comparing VEH/CIS to ARI3/CIS; two-way ANOVA with Tukey's posttest.

2.4. Cisplatin Elicits a Decrease in Neurite Outgrowth in Cultures of Sensory Neurons, and This Is Partially Attenuated by Inhibition of OGG1 Glycosylase Activity

Chemotherapeutics are known to induce a loss of epidermal innervation in cancer patients [38], and this effect has been recapitulated in vitro, where the exposure of sensory neuronal cultures to various different chemotherapeutics induces a loss of neurite length and/or branching [39-41]. To determine whether inhibition of the base excision repair pathway alters the effects of cisplatin to diminish neurite outgrowth, we exposed neuronal cultures to TH5487 $(3 \mu \mathrm{M})$, ARI3 $(10 \mu \mathrm{M})$, or to vehicle controls for $48 \mathrm{~h}$ and then added vehicle or cisplatin $(30 \mu \mathrm{M})$ for the last $24 \mathrm{~h}$ in culture prior to fixation of the cells to assess neurite areas. As pictured in Figure 4A, the treatment with BER inhibitors alone did not alter neurite outgrowth. As we expected, cisplatin diminished the neurite area per neuron captured from $1.4 \pm 0.3$ in the presence of vehicle to $0.4 \pm 0.1 \mu \mathrm{m}^{2}$ following a $24 \mathrm{~h}$ cisplatin treatment (Figure 4B). Interestingly, we saw that pretreatment with the OGG1 inhibitor partially attenuate the loss of neurite area in the presence of cisplatin treatment to $0.9 \pm 0.1 \mu \mathrm{m}^{2}$; however, there was no effect of inhibition of APE1-mediated DNA repair on the neurite area following cisplatin treatment (Figure 5). 
A
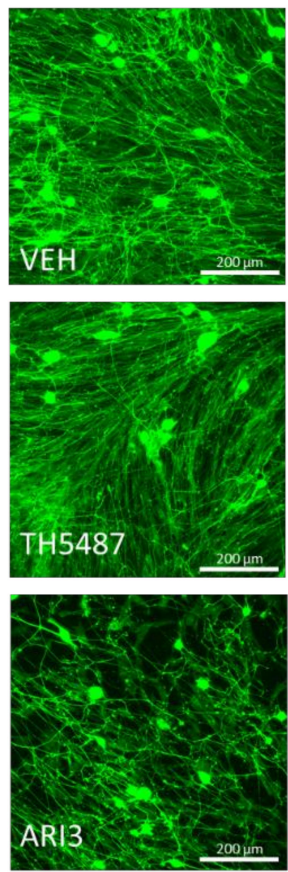
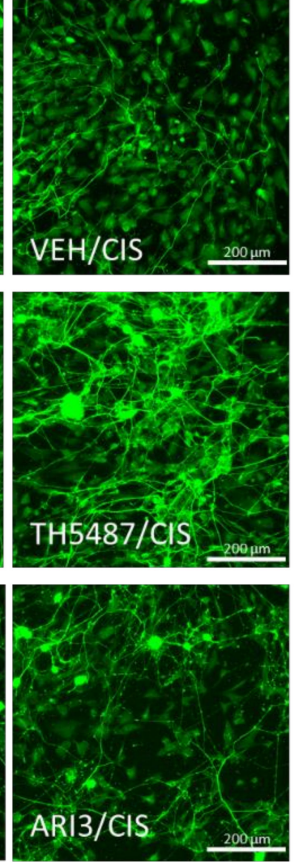

B

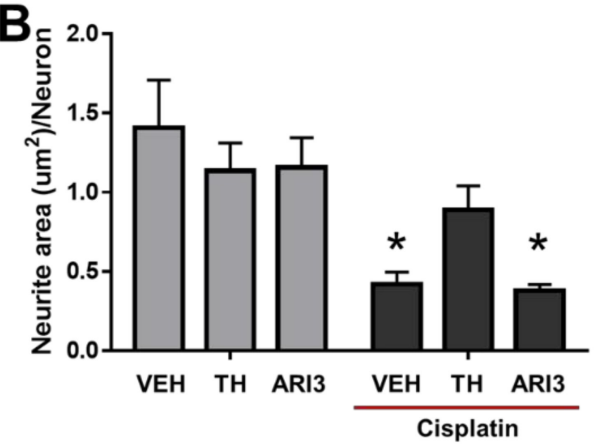

Figure 5. Effects of cisplatin and base excision repair inhibitors on neurite outgrowth. (A) Representative immunostaining for PGP9.5 (green) in sensory neuron cultures. The original magnification was $\times 20$. Scale bar represents $200 \mu \mathrm{m}$. (B) Quantitative analysis of the axonal area of PGP9.5 staining, acquired using Cytation5 software. ${ }^{*} p<0.01$ comparing the indicated groups to the Vehicle-treated control, two-way ANOVA with Tukey's posttest.

\section{Discussion}

It is well established that treating animals with cisplatin results in the production of platinum adducts in sensory neurons $[35,36]$ and levels of adduct formation have been correlated with the degree of toxicity to the peripheral sensory neurons $[8,42]$. The nucleotide excision repair (NER) pathway catalyzes the removal of cisplatin adducts from nuclear DNA and actively repairs nuclear adducts in sensory neurons [37,43]. Indeed, our data suggest a very robust clearance of adducts following exposure to cisplatin, as we did not observe significant adduct accumulation in the absence of DNA repair inhibitors. Furthermore, investigational drugs that increase the clearance of nuclear cisplatin adducts in sensory neurons diminish the neurotoxicity induced by cisplatin [9].

In addition to alterations in nuclear transcription through the formation of cisplatin adducts within nuclear DNA, cisplatin can also form adducts within the mitochondrial DNA (mtDNA). As NER is thought to be ineffective or minimal in mitochondria [44,45], adduct damage in the mitochondria of sensory neurons can have long-term effects on mitochondrial function. Podratz and colleagues [4] demonstrated a correlation between cisplatin-induced decreases in mtDNA replication and the diminished transcription of mitochondrial transcripts. Aberrant expression of mitochondrial transcripts could contribute to deficiencies of the neuronal mitochondria following exposure of the neurons to cisplatin. Alternatively, mitochondrial DNA damage could serve to recruit p53 to the mitochondria, which has been shown to alter mitochondrial bioenergetics and contribute to ROS generation and oxidative DNA damage [9,46-48].

Cisplatin-DNA adducts are not the only type of DNA lesions produced by neuronal exposure to cisplatin. Oxidative damage is also induced by cisplatin [13,48,49], resulting in the formation of 8-oxodG lesions in DNA and RNA. Inhibition of either OGG1 glycosylase activity or APE1 DNA repair activity resulted in an increase in 8-oxodG lesions in sensory neuron cultures, supporting the notion that the BER pathway is very active. In fact, we did not observe an increase in 8-oxodG lesions induced by cisplatin, unless we inhibited the BER pathway, suggesting that the cells are constantly repairing the damage induced 
by cisplatin. Although we were focused on DNA damage repair, the antibody that we use to detect 8-oxodG lesions likely recognizes both DNA and RNA 8-oxodG. Therefore, we included RNase A to limit our findings, specifically to 8-oxodG lesions on DNA. It is unclear, however, what impact the DNA lesions themselves or the repair of the lesions might have on sensory neuron function. Oxidative DNA damage was thought to disrupt transcription by preventing transcription factor binding to consensus sequences within gene promoter elements [24-26] and by stalling the progress of RNA polymerase II during transcription [27]. Transcriptional repression secondary to oxidative damage, however, has been shown to be dependent upon an abasic site produced by OGG1-induced lysis of 8-oxodG, suggesting that BER activity is essential to observe effects of oxidative lesions [50]. In an opposite role, OGG1 bound to 8-oxodG has been reported to serve as an epigenetic mark to enhance gene transcription secondary to inflammatory stimuli by increasing the recruitment of transcription factors to promoter elements of genes [28,51]. Furthermore, the bound 8-oxodG:OGG1 complex has been shown to have signal transduction functions, including Ras and Rho activation [52,53]. Advanced investigation into the mechanisms by which the BER enzymes enhance transcription has identified the formation of guaninerich G-quadruplexes within the promoter sequences of genes differentially regulated by oxidative damage [43]. G-quadruplexes (G4) are secondary structures of guanine-rich nucleic acids that form a helical structure due to guanine: guanine interactions and are commonly seen in promoter regions, $5^{\prime}$ and $3^{\prime}$ untranslated regions, and within telomeric regions of DNA [54]. In addition to G-quadruplexes, oxidative DNA damage has also been shown to alter cruciform DNA sequences in the promoter elements of genes [55]. The formation of G4 and cruciform structures can enhance or repress the transcription of genes, depending on whether the secondary structure forms within the template or nontemplate strands $[55,56]$, thus oxidation-induced increases in DNA secondary structures provide another means by which oxidative damage alters gene transcription. Recent reports suggest that APE1 binding to AP sites within G4 sequences increases the folding of DNA into G4 structures and maintenance of APE1 binding, via APE1 acetylation, stabilizes the G4 and increases transcription factor recruitment to the promoter [29]. The effects of APE1 are not limited to DNA, as recent developments demonstrate that APE1 is also involved in the repair of damaged RNA, particularly oxidatively damaged RNA [57-59]. A clear understanding of what precedes APE1 activity on ribose AP sites is unclear; however, we cannot exclude the possibility that cisplatin also enhances the formation of 8-oxodG lesions within RNA and that APE1 can play a role in repairing the oxidative damage in RNA.

Although we did not observe the presence of oxidative lesions $6 \mathrm{~h}$ after the start of cisplatin treatment, we did observe effects of cisplatin on neuronal function, which was altered by inhibitors of the BER pathway. The effects of the BER inhibitors could be interpreted in alternate ways, due to the inverse U-shaped cisplatin concentration curve and further experiments are needed to conclusively identify whether the inhibitors have a neuroprotective or neurotoxic effect. The effect of BER inhibitors to reduce the sensitizing effects of cisplatin could be interpreted as a true inhibition of the effects of cisplatin. Alternatively, the BER inhibitors might be creating a rightward shift in the cisplatin concentration curve so that, with the inhibitor treatments, the effects of cisplatin are exacerbated and produce desensitizing effects on release (Figures 1A and 2A). We previously demonstrated that overexpressing endonuclease-competent APE1 or pharmacologically increasing APE1 DNA repair activity is neuroprotective against the effects of cisplatin in sensory neurons $[7,22,60]$, which would support the latter interpretation: a role for the inhibitors to exacerbate cisplatin-induced neurotoxicity. However, the precise mechanisms by which oxidative DNA damage or the repair thereof alters neuronal function are still unclear. In order to determine which aspect of cisplatin-induced DNA damage leads to neurotoxicity, we used selective inhibition of either OGG1, APE1 or a combined inhibition of both BER enzymes. It is known that base excision repair enzymes work in concert to facilitate DNA repair: OGG1 has higher specificity for 8-oxodG [61], cleaves the lesioned base at a higher rate, and has a lower affinity for the abasic site to facilitate APE1 binding and endonuclease activity [62] when 
APE1 is present. Indeed, we observed equivalent effects of inhibiting either enzyme on both the presence of 8-oxodG lesions and the modulation of neuropeptide release, suggesting that OGG1 activity to remove a lesioned base is dependent upon APE1 activity in sensory neuron cultures. Combined inhibition of OGG1 and APE1 did not have a significant impact on CGRP release compared with either drug alone, suggesting that neither enzyme has a role outside of the BER pathway to alter neuronal function. This was a little surprising, as we demonstrated some crosstalk between APE1 and the NER DNA repair pathway, as inhibition of APE1 enhanced the levels of cisplatin adducts. These findings corroborate our previous findings, that cisplatin adducts were enhanced by knockdown of APE1/Ref-1 expression and diminished by overexpression of APE1/Ref-1 [37]. However, previous work by others has demonstrated a correlation between platin adduct formation and neurotoxicity effects [8,42]; therefore, we will continue to examine the role of APE1 in the NER pathway. Interestingly, the interactions between APE1 and the NER pathway may be cell-dependent, as APE1 did not promote adduct repair in some cancer cells [23,63]. An interaction of BER proteins with other DNA repair pathways has been observed [64]; for example, Pol $\beta$ polymerase can recruit mismatch repair (MMR) proteins [65] and the BER proteins, APE1 and PARP1, interact directly with Cockayne Syndrome B protein, which is critical for transcription-coupled and global nucleotide excision repair [66]. In addition to endonuclease/lyase functions to repair DNA damage, APE1 binds to RNA and may contribute to phase separation to organize biocondensates, which could enhance BER [59]. These findings support the notion that APE1 may modulate the DNA damaging effects of cisplatin beyond the repair of oxidative DNA lesions, suggesting that manipulation of the BER pathway may have indirect consequences on other DNA repair pathways and vice versa. Because OGG1 and APE1 work in a linear pathway to repair 8-oxodG lesions, we do not anticipate an additive effect on the inhibitors to alter the presence of 8-oxodG. However, we will examine that possibility in future experiments. Similarly, we will assess the combination drug effect on adduct formation, since OGG1 inhibition seemed to have a small effect on adduct levels in sensory neurons.

In addition to changes in neuronal sensitivity induced by cisplatin, chemotherapeutics can also drive reductions in intraepidermal innervation of the skin (in vivo) and neurite length (in vitro) [39-41,67]. We first examined whether inhibiting the activity of either OGG1 and APE1 would alter neurite outgrowth, but saw no effect of either drug. Interestingly, we found that inhibition of OGG1 abrogated the effects of cisplatin to decrease neurite outgrowth. It is unclear how DNA damage or OGG1 intracellular signaling might alter outgrowth. Signaling by RhoA in sensory neurons has been shown to negatively regulate neurite outgrowth [68]. Cisplatin could enhance RhoA activation via engagement of OGG1:8-oxydG signaling to induce neurite retraction, and thus inhibition of OGG1 could reverse the effects of cisplatin to decrease outgrowth. Because of the rescue effect of OGG1 inhibition and apparent lack of effect of APE1 inhibition on neurite outgrowth, we did not test the effects of the drugs in combination. Further studies will be performed to investigate the effects of a RhoA inhibitor on cisplatin-induced changes in neurite outgrowth.

Recent reports suggest that cisplatin can elicit the transition of sensory neurons into a senescent-like state $[69,70]$. Senescence in post-mitotic neurons of the central nervous system can be driven by numerous cell stressors, including DNA damage and oxidative stress, and is understood to be a way to accommodate stress without eliciting apoptosis [71]. However, senescent cells are known to release cytokines and chemokines (senescenceassociated secretory phenotype) [72], which could result in the sensitization of neighboring non-senescent cells. Indeed, in an animal model whereby senescent cells could be selectively ablated, cisplatin-induced neuropathy is alleviated [70]. APE1 deficiency in primary fibroblasts contributes to the development of senescence [73]. Future studies in our laboratory will elucidate the contribution of DNA damage to the initiation of cisplatin-induced senescence in sensory neurons and determine whether increasing APE1 DNA repair activity could prevent the onset of senescence. 
Based upon the above studies, we propose a model for cisplatin-induced neurotoxicity that is likely mediated by oxidative DNA damage (Figure 6), suggesting that the enhanced activation of OGG1 and APE1 endonuclease activity would ameliorate neurotoxicity. One limitation of our study is that we largely limited our examination to peptidergic sensory neurons. Further work will determine whether cisplatin induces DNA damage in all of the subpopulations of sensory neurons in a similar manner. Future studies will more precisely dissect the function of OGG1 and APE1 to examine how the activity of these proteins alters sensory neuron function.

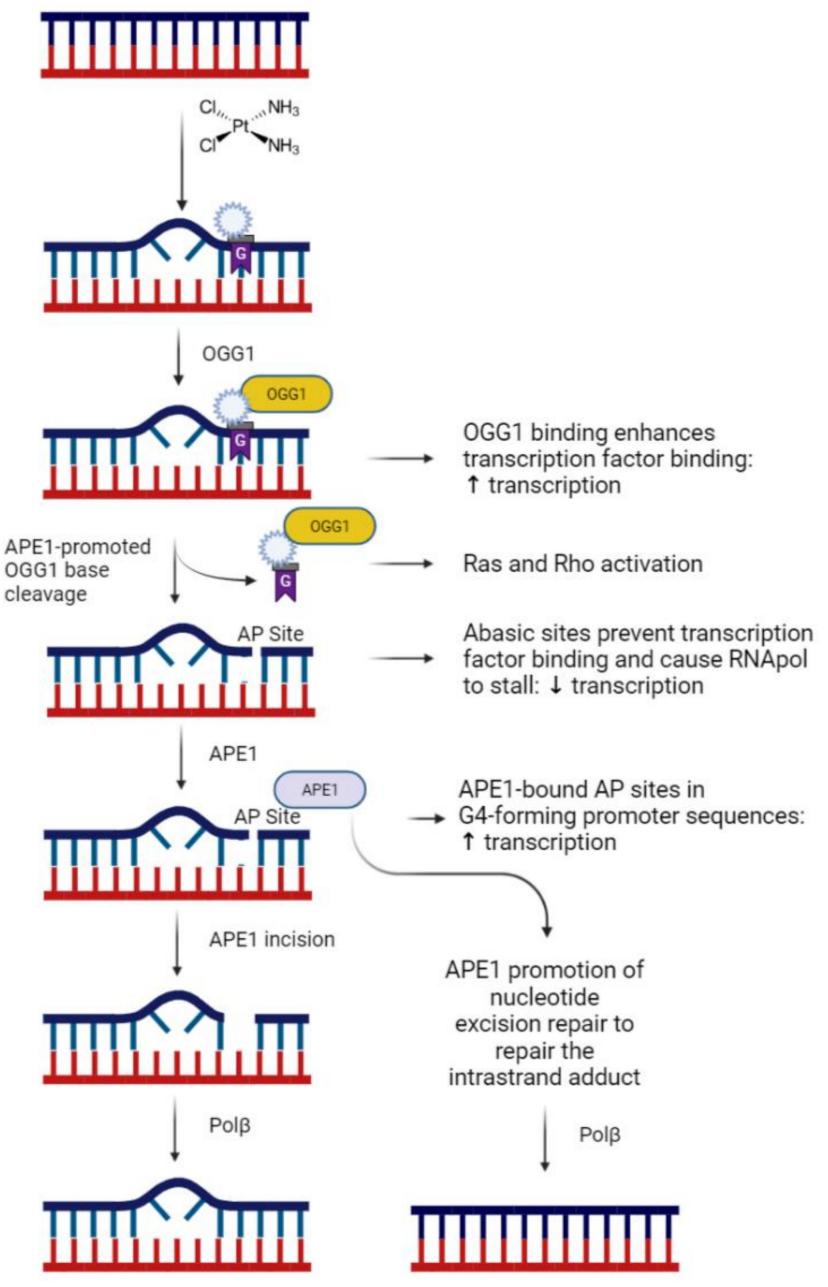

Figure 6. A summary of the proposed roles of oxidative DNA damage, OGG1 and APE1 in sensory neurons. Figure created with Biorender.com, accessed on 29 December 2021.

\section{Materials and Methods}

\subsection{Animals}

Experiments were conducted according to protocols approved by the Institutional Animal Care and Use Committee at Indiana University School of Medicine (protocol \#20098), Indianapolis, IN and in compliance with the National Institutes of Health Guide for the Care and Use of Laboratory Animals. Experiments were performed on primary cultures of sensory neurons derived from the DRG of adult male Sprague Dawley rats (150-250 g; Envigo, Indianapolis, IN, USA). Animals were housed in group cages in a light-controlled room with food and water available ad libitum.

\subsection{Isolation of Primary Sensory Neuron Cultures}

DRG were harvested and cultured as described previously [34]. Dissociated DRG cells were added to plates previously coated with poly-D-lysine and laminin $[\sim 15,000$ cells / well 
in 24-well plates for CGRP release assays and neurite imaging experiments and 2000 cells/well in 4-well chamber slides for the assessment of DNA damage]. Cells were grown in F-12 growth media supplemented with 10\% heat-inactivated horse serum, $2 \mathrm{mM}$ glutamine, and $50 \mu \mathrm{g} / \mathrm{mL}$ penicillin and streptomycin in the presence of $10 \mathrm{ng} / \mathrm{mL}$ NGF. Cells were maintained in an atmosphere of $3 \% \mathrm{CO}_{2}$ at $37{ }^{\circ} \mathrm{C}$, and media was changed every other day. Stocks (10 mM) of the OGG1 and APE1 inhibitors [28,74,75], TH5487 and ARI3, were prepared in N-Methyl-2-pyrrolidone and diluted in media to the appropriate concentrations (TH5487: $3 \mu \mathrm{M}$; ARI3: $10 \mu \mathrm{M}$ ) and exposed to the treatment wells for $48 \mathrm{~h}$ prior to release or fixation. For cisplatin treatment, a $3 \mathrm{mM}$ stock was prepared from cisplatin powder (Millipore-Sigma, St. Louis, MO, USA, Cat\#: 232120) biweekly in sterile water by vortexing and overnight incubation at $37^{\circ} \mathrm{C}$, with subsequent storage at RT while being protected from light. The stock was further diluted in media to various concentrations for treatment. Cultures were treated with cisplatin for 6 or $24 \mathrm{~h}$, starting on day 6 in culture, for DNA damage and release/neurite outgrowth experiments, respectively.

\subsection{Calcitonin Gene-Related Peptide Release}

Release experiments were performed as described previously [7,34]. The wells were rinsed one time with HEPES buffer containing $25 \mathrm{mM} \mathrm{HEPES,} 135 \mathrm{mM} \mathrm{NaCl}, 3.5 \mathrm{mM} \mathrm{KCl}$, $2.5 \mathrm{mM} \mathrm{CaCl}_{2}, 1 \mathrm{mM} \mathrm{MgCl} 2,3.3 \mathrm{mM}$ D-glucose, and $0.1 \%$ bovine serum albumin, $\mathrm{pH}$ 7.4. The cells were maintained at $37^{\circ} \mathrm{C}$ for 3 incubations. During the first interval, cells were incubated with HEPES buffer for $20 \mathrm{~min}$ to establish resting basal release of immunoreactive CGRP (iCGRP), which we will refer to as CGRP. During the second interval, cells were incubated with HEPES containing $30 \mathrm{nM}$ capsaicin in order to stimulate CGRP release. The third incubation was in HEPES to reestablish resting basal release. Supernatants were collected after every interval, and CGRP was measured using radioimmunoassay as previously described $[7,34]$. At the completion of the release experiment, cells were incubated for $20 \mathrm{~min}$ in $0.1 \mathrm{~N} \mathrm{HCl}$, and the supernatant was collected to determine total CGRP content. Release and total content of CGRP from each individual well of sensory neurons was considered an independent replicate; however, these cultures were derived from a minimum of 3 rats.

\subsection{Neurite Length Assessment}

Plates were fixed with 4\% paraformaldehyde for $20 \mathrm{~min}$ at RT and washed in PBS. Slides were blocked with 5\% normal donkey serum for $1 \mathrm{~h}$ at RT and then washed 3 times in PBS. Chicken anti- PGP9.5 (1:250 dilution; Cat\#: PA1-10011, Thermo Fisher Scientific, Waltham, MA, USA) antibody in 5\% normal donkey serum and 0.05\% Triton-X100 was added to the plate and it was incubated in a humidified chamber at $4{ }^{\circ} \mathrm{C}$ overnight. The wells were washed three times with PBS for 5 min each. Donkey anti-rabbit Alexa Fluor 647 conjugate (1:250 dilution; Cat\#: 703-605-155, Jackson ImmunoResearch Labs, West Grove, PA, USA) was added to the plate for $2 \mathrm{~h}$ at RT in the dark. The wells were briefly washed 3 times using PBS. The plate was placed in the Cytation 5 Cell Imaging Multi-Mode Reader (BioTek Instruments, Winooski, VT, USA) and images were obtained using the Cy5 channel using the following parameters for cell bodies (min width of cell body: $25 \mu \mathrm{m}$, max width of cell body: $100 \mu \mathrm{m}$, detection threshold: 15,000 pixel intensity) and outgrowths (detection threshold: 10,000 pixel intensity, minimum cell growth to log as significant: $10 \mu \mathrm{m})$, modified from Pittman et al. [41]. 23-25 images each with an area of $394 \times 291 \mu \mathrm{m}$ were taken for each experimental condition, and the automated rolling ball algorithm was used to remove neuronal cell bodies and the remaining neurites were analyzed for Total Neurite Area measured in microns using Microsoft Excel (Microsoft Corporation, Redmond, WA, USA) and GraphPad Prism Version 7 (GraphPad Software, La Jolla, CA, USA). 


\subsection{Staining and Quantification of 7,8-Dihydro-8-oxo-2'-deoxyguanosine (8-oxodG) and Cisplatin Adducts}

Cultures, treated with vehicle or cisplatin $(30 \mu \mathrm{M})$ for $6 \mathrm{~h}$, were fixed for at least 20 min to overnight in $-20{ }^{\circ} \mathrm{C}$ methanol stored at $-20^{\circ} \mathrm{C}$, followed by $-20{ }^{\circ} \mathrm{C}$ acetone for $15 \mathrm{~min}$ in $-20^{\circ} \mathrm{C}$. Wells were then air-dried and washed 3 times in PBS for $5 \mathrm{~min}$ each. Cells were treated with $100 \mathrm{ug} / \mathrm{mL}$ RNase (Thermo-Fisher) in $150 \mathrm{mM}$ sodium chloride, and $15 \mathrm{mM}$ sodium citrate incubated for $1 \mathrm{~h}$ at $37^{\circ} \mathrm{C}$. Slides were then washed sequentially for 3 min each with: PBS, 35\% ethanol, 50\% ethanol, and 75\% ethanol at RT. Slides were then treated with $0.15 \mathrm{~N} \mathrm{NaOH}$ in $70 \% \mathrm{EtOH}$ for $8 \mathrm{~min}$ at room temperature and then washed in PBS. Slides were then washed sequentially for 2 min each at RT with $4 \%$ paraformaldehyde in $70 \% \mathrm{EtOH}, 50 \%$ ethanol, 35\% ethanol, PBS. Slides were then incubated for $10 \mathrm{~min}$ with $5 \mathrm{ug} / \mathrm{mL}$ proteinase $\mathrm{K}$ in $20 \mathrm{mM}$ Tris, $1 \mathrm{mM}$ EDTA at $\mathrm{pH}$ of 7.5 in $37^{\circ} \mathrm{C}$. Slides were washed 3 times in PBS at RT. Slides were blocked with $5 \%$ normal donkey serum for $1 \mathrm{~h}$ at RT and then washed 3 times in PBS. Mouse anti8-oxodG (1:250 dilution; Cat\#: 4354-MC-050, R\&D Systems, Minneapolis, MN, USA), rabbit anti-cisplatin modified DNA [CP9/19] (1:500 dilution; Cat\#: Ab00612-23, Absolute Antibody, Wilton, UK), and chicken anti-PGP9.5 (1:250 dilution; Cat\#: PA1-10011, Thermo Fisher Scientific) antibodies in 1\% BSA and 0.01\% Tween-20 were added to the slides and incubated in a humidified chamber at $4{ }^{\circ} \mathrm{C}$ overnight. Slides were washed three times with PBS containing 0.05\% Tween-20 for 5 min each. Donkey anti-Mouse Alexa Fluor 488 conjugate (Cat\#: A21202, Thermo Fisher Scientific), donkey anti-Rabbit Alexa Fluor 568 conjugate (Cat\#: A10042, Thermo Fisher Scientific), and donkey anti-chicken Alexa Fluor 647 (Cat\#: 703-605-155, Jackson ImmunoResearch) secondary antibodies, all at 1:250 dilution, were added to the slides for $1 \mathrm{~h}$ at RT in the dark. Slides were briefly washed 3 times using PBS containing 0.05\% Tween-20, and then with de-ionized water prior to removal of the gaskets per manufacturer's instructions. Slides were coverslipped with VectaShield antifade mounting media containing DAPI (Cat\#: H-1800-10, Vector Labs, Burlingame, CA, USA). Z-stack images were taken with the Cytation 5 Cell Imaging Multi-Mode Reader (BioTek Instruments) and GFP and TRITC channel measurements of integrated density were used for analysis of immunofluorescence images [76]. Cytation 5 automated image preprocessing and background flattening was carried out, followed by five iterations of deconvolution based on image objective. A DAPI mask was established using a threshold of 5000-pixel intensity and was applied to images for PGP9.5, where the PGP9.5 mask was established with a threshold of greater than or equal to 14,120-pixel intensity. The ROIs for 8-oxodG and DNA adducts were measured for integrated density relative to DAPI-integrated density within the mask for PGP9.5. Threshold levels were optimized by comparing ROIs generated to true neurons in the images and all parameters remained consistent for all images processed.

\subsection{Reagents}

All materials, unless stated otherwise, were purchased from Millipore-Sigma (St. Louis, MO, USA). F-12 media, horse serum, antibiotics, Nunc ${ }^{\mathrm{TM}}$ Lab-Tek $^{\mathrm{TM}}$ II Chamber Slides $^{\text {TM }}$ (Cat\#: 154526) and RNase (Cat \#: EN0531) were acquired from Thermo Fisher Scientific. Paraformaldehyde (32\% aqueous solution; Cat\#: 15714S) was acquired from Electron Microscopy Sciences (Hatfield, PA, USA), the proteinase K $(20 \mathrm{mg} / \mathrm{mL}$; Cat\#: 501-PK) from Viagen Biotech (Los Angeles, CA, USA), and the normal donkey serum (Cat\#: 017-000-121) was acquired from Jackson ImmunoResearch (West Grove, PA, USA). TH5487 was acquired from Tocris (Cat\#: 6749) and ARI3 from Millipore-Sigma (St. Louis, MO, USA; Cat\#: 262017).

\subsection{Statistical Analysis}

Data were analyzed by one-way analysis of variance (ANOVA) or two-way ANOVA as indicated, and post hoc analyses were performed using Tukey's or Dunnett's test, as indicated. Statistical calculations were performed with the GraphPad Prism version 
6.02 statistical software (GraphPad Software, La Jolla, CA, USA). Data are presented as mean \pm SEM, and differences are considered significant if $p<0.05$.

Author Contributions: Conceptualization, J.C.F. and M.R.K.; methodology, J.C.F., A.B., H.X. and M.R.K.; Investigation, A.B. and E.L.T.; writing—original draft preparation, J.C.F.; writing-review and editing, A.B. and M.R.K.; funding acquisition, J.C.F. and M.R.K. All authors have read and agreed to the published version of the manuscript.

Funding: Financial support for this work was provided by the National Institutes of Health by the National Cancer Institute CA205166 (M.K. and J.F.), CA231267 (J.F. and M.K.), CA167291 (M.K.) and CA254110 (M.K.), as well as EY031939 and HL140961 (M.K.). Additional financial support was provided by the Earl and Betty Herr Professor in Pediatric Oncology Research, the Jeff Gordon Children's Foundation, the Riley Children's Foundation (M.K.), and the IU Simon Comprehensive Cancer Center, P30CA082709.

Institutional Review Board Statement: All animal procedures were approved by the Institutional Animal Care and Use Committee at Indiana University (Protocol 20098, approved 11/02/2020).

Informed Consent Statement: Not applicable.

Data Availability Statement: The data presented in this study are available within the article.

Conflicts of Interest: The authors declare no conflict of interest. The funders had no role in the design of the study; in the collection, analyses, or interpretation of data; in the writing of the manuscript, or in the decision to publish the results.

\section{References}

1. Seretny, M.; Currie, G.L.; Sena, E.S.; Ramnarine, S.; Grant, R.; MacLeod, M.R.; Colvin, L.A.; Fallon, M. Incidence, prevalence, and predictors of chemotherapy-induced peripheral neuropathy: A systematic review and meta-analysis. Pain 2014, 155, 2461-2470. [CrossRef] [PubMed]

2. Kelland, L. The resurgence of platinum-based cancer chemotherapy. Nat. Rev. Cancer 2007, 7, 573-584. [CrossRef] [PubMed]

3. Podratz, J.L.; Lee, H.; Knorr, P.; Koehler, S.; Forsythe, S.; Lambrecht, K.; Arias, S.; Schmidt, K.; Steinhoff, G.; Yudintsev, G.; et al. Cisplatin induces mitochondrial deficits in Drosophila larval segmental nerve. Neurobiol. Dis. 2017, 97, 60-69. [CrossRef] [PubMed]

4. Podratz, J.L.; Knight, A.M.; Ta, L.E.; Staff, N.P.; Gass, J.M.; Genelin, K.; Schlattau, A.; Lathroum, L.; Windebank, A.J. Cisplatin induced mitochondrial DNA damage in dorsal root ganglion neurons. Neurobiol. Dis. 2011, 41, 661-668. [CrossRef] [PubMed]

5. Bobylev, I.; Joshi, A.R.; Barham, M.; Neiss, W.F.; Lehmann, H.C. Depletion of Mitofusin-2 Causes Mitochondrial Damage in Cisplatin-Induced Neuropathy. Mol. Neurobiol. 2018, 55, 1227-1235. [CrossRef] [PubMed]

6. Leo, M.; Schmitt, L.I.; Kusterarent, P.; Kutritz, A.; Rassaf, T.; Kleinschnitz, C.; Hendgen-Cotta, U.B.; Hagenacker, T. Platinum-Based Drugs Cause Mitochondrial Dysfunction in Cultured Dorsal Root Ganglion Neurons. Int. J. Mol. Sci. 2020, 21, 8636. [CrossRef]

7. Kelley, M.R.; Jiang, Y.; Guo, C.; Reed, A.; Meng, H.; Vasko, M.R. Role of the DNA base excision repair protein, APE1 in cisplatin, oxaliplatin, or carboplatin induced sensory neuropathy. PLoS ONE 2014, 9, e106485. [CrossRef]

8. Dzagnidze, A.; Katsarava, Z.; Makhalova, J.; Liedert, B.; Yoon, M.S.; Kaube, H.; Limmroth, V.; Thomale, J. Repair capacity for platinum-DNA adducts determines the severity of cisplatin-induced peripheral neuropathy. J. Neurosci. 2007, 27, 9451-9457. [CrossRef]

9. Gorgun, M.F.; Zhuo, M.; Englander, E.W. Cisplatin Toxicity in Dorsal Root Ganglion Neurons Is Relieved by Meclizine via Diminution of Mitochondrial Compromise and Improved Clearance of DNA Damage. Mol. Neurobiol. 2017, 54, 7883-7895. [CrossRef]

10. Jirsova, K.; Mandys, V. Differences in the inhibition of neuritic outgrowth in organotypic cultures of rat foetal dorsal root ganglia treated with cisplatin and carboplatin: A comparative study. Folia Histochem. Cytobiol. 1997, 35, 215-219.

11. Donaldson, K.L.; Goolsby, G.L.; Wahl, A.F. Cytotoxicity of the anticancer agents cisplatin and taxol during cell proliferation and the cell cycle. Int. J. Cancer 1994, 57, 847-855. [CrossRef]

12. Kim, Y.K.; Jung, J.S.; Lee, S.H.; Kim, Y.W. Effects of antioxidants and Ca2+ in cisplatin-induced cell injury in rabbit renal cortical slices. Toxicol. Appl. Pharm. 1997, 146, 261-269. [CrossRef]

13. Siomek, A.; Tujakowski, J.; Gackowski, D.; Rozalski, R.; Foksinski, M.; Dziaman, T.; Roszkowski, K.; Olinski, R. Severe oxidatively damaged DNA after cisplatin treatment of cancer patients. Int. J. Cancer 2006, 119, 2228-2230. [CrossRef]

14. Fishel, M.L.; Vasko, M.R.; Kelley, M.R. DNA repair in neurons: So if they don't divide what's to repair? Mutat. Res. 2007, 614, 24-36. [CrossRef]

15. Yan, F.; Liu, J.J.; Ip, V.; Jamieson, S.M.; McKeage, M.J. Role of platinum DNA damage-induced transcriptional inhibition in chemotherapy-induced neuronal atrophy and peripheral neurotoxicity. J. Neurochem. 2015, 135, 1099-1112. [CrossRef]

16. Cadet, J.; Douki, T.; Ravanat, J.L. One-electron oxidation of DNA and inflammation processes. Nat. Chem. Biol. 2006, 2, 348-349. [CrossRef] 
17. Margolin, Y.; Cloutier, J.F.; Shafirovich, V.; Geacintov, N.E.; Dedon, P.C. Paradoxical hotspots for guanine oxidation by a chemical mediator of inflammation. Nat. Chem. Biol. 2006, 2, 365-366. [CrossRef]

18. Steenken, S.; Jovanovic, S.V. How Easily Oxidizable Is DNA? One-Electron Reduction Potentials of Adenosine and Guanosine Radicals in Aqueous Solution. J. Am. Chem. Soc. 1997, 119, 617-618. [CrossRef]

19. Monden, Y.; Arai, T.; Asano, M.; Ohtsuka, E.; Aburatani, H.; Nishimura, S. Human MMH (OGG1) type 1a protein is a major enzyme for repair of 8-hydroxyguanine lesions in human cells. Biochem. Biophys. Res. Commun. 1999, 258, 605-610. [CrossRef]

20. Singhal, R.K.; Prasad, R.; Wilson, S.H. DNA polymerase beta conducts the gap-filling step in uracil-initiated base excision repair in a bovine testis nuclear extract. J. Biol. Chem. 1995, 270, 949-957. [CrossRef]

21. Vasko, M.R.; Guo, C.; Thompson, E.L.; Kelley, M.R. The repair function of the multifunctional DNA repair/redox protein APE1 is neuroprotective after ionizing radiation. DNA Repair 2011, 10, 942-952. [CrossRef] [PubMed]

22. Jiang, Y.; Guo, C.; Vasko, M.R.; Kelley, M.R. Implications of apurinic/apyrimidinic endonuclease in reactive oxygen signaling response after cisplatin treatment of dorsal root ganglion neurons. Cancer Res. 2008, 68, 6425-6434. [CrossRef] [PubMed]

23. Sawant, A.; Floyd, A.M.; Dangeti, M.; Lei, W.; Sobol, R.W.; Patrick, S.M. Differential role of base excision repair proteins in mediating cisplatin cytotoxicity. DNA Repair 2017, 51, 46-59. [CrossRef] [PubMed]

24. Hailer-Morrison, M.K.; Kotler, J.M.; Martin, B.D.; Sugden, K.D. Oxidized guanine lesions as modulators of gene transcription Altered p50 binding affinity and repair shielding by 7,8-dihydro-8-oxo-2'-deoxyguanosine lesions in the NF-kappaB promoter element. Biochemistry 2003, 42, 9761-9770. [CrossRef]

25. Ramon, O.; Sauvaigo, S.; Gasparutto, D.; Faure, P.; Favier, A.; Cadet, J. Effects of 8-oxo-7,8-dihydro-2'-deoxyguanosine on the binding of the transcription factor Sp1 to its cognate target DNA sequence (GC box). Free Radic. Res. 1999, 31, 217-229. [CrossRef]

26. Moore, S.P.; Toomire, K.J.; Strauss, P.R. DNA modifications repaired by base excision repair are epigenetic. DNA Repair 2013, 12, 1152-1158. [CrossRef] [PubMed]

27. Tornaletti, S.; Maeda, L.S.; Kolodner, R.D.; Hanawalt, P.C. Effect of 8-oxoguanine on transcription elongation by T7 RNA polymerase and mammalian RNA polymerase II. DNA Repair 2004, 3, 483-494. [CrossRef]

28. Visnes, T.; Cazares-Korner, A.; Hao, W.; Wallner, O.; Masuyer, G.; Loseva, O.; Mortusewicz, O.; Wiita, E.; Sarno, A.; Manoilov, A.; et al. Small-molecule inhibitor of OGG1 suppresses proinflammatory gene expression and inflammation. Science 2018, 362, 834-839. [CrossRef]

29. Roychoudhury, S.; Pramanik, S.; Harris, H.L.; Tarpley, M.; Sarkar, A.; Spagnol, G.; Sorgen, P.L.; Chowdhury, D.; Band, V.; Klinkebiel, D.; et al. Endogenous oxidized DNA bases and APE1 regulate the formation of G-quadruplex structures in the genome. Proc. Natl. Acad. Sci. USA 2020, 117, 11409-11420. [CrossRef]

30. Feghali, J.G.; Liu, W.; Van De Water, T.R. L-n-acetyl-cysteine protection against cisplatin-induced auditory neuronal and hair cell toxicity. Laryngoscope 2001, 111, 1147-1155. [CrossRef]

31. Van den Berg, J.H.; Beijnen, J.H.; Balm, A.J.; Schellens, J.H. Future opportunities in preventing cisplatin induced ototoxicity. Cancer Treat. Rev. 2006, 32, 390-397. [CrossRef]

32. Haihong, Z.; Takatsugu, M.; Jaime, C.-T.; Liwen, L.; Akihiro, N.; Horace, J.S.; Paul, M.S.; Bruce, R.S.; Amanda, J.W.; Geoffrey, P.M.; et al. Targeting human 8-oxoguanine DNA glycosylase (hOGG1) to mitochondria enhances cisplatin cytotoxicity in hepatoma cells. Carcinogenesis 2007, 28, 1629-1637.

33. David, S.S.; O'Shea, V.L.; Kundu, S. Base-excision repair of oxidative DNA damage. Nature 2007, 447, 941-950. [CrossRef] [PubMed]

34. Pittman, S.K.; Gracias, N.G.; Vasko, M.R.; Fehrenbacher, J.C. Paclitaxel alters the evoked release of calcitonin gene-related peptide from rat sensory neurons in culture. Exp. Neurol. 2014, 253, 146-153. [CrossRef]

35. Meijer, C.; de Vries, E.G.; Marmiroli, P.; Tredici, G.; Frattola, L.; Cavaletti, G. Cisplatin-induced DNA-platination in experimental dorsal root ganglia neuronopathy. Neurotoxicology 1999, 20, 883-887. [PubMed]

36. McDonald, E.S.; Randon, K.R.; Knight, A.; Windebank, A.J. Cisplatin preferentially binds to DNA in dorsal root ganglion neurons in vitro and in vivo: A potential mechanism for neurotoxicity. Neurobiol. Dis. 2005, 18, 305-313. [CrossRef]

37. Kim, H.S.; Guo, C.; Thompson, E.L.; Jiang, Y.; Kelley, M.R.; Vasko, M.R.; Lee, S.H. APE1, the DNA base excision repair protein, regulates the removal of platinum adducts in sensory neuronal cultures by NER. Mutat. Res. 2015, 779, 96-104. [CrossRef]

38. Boyette-Davis, J.A.; Cata, J.P.; Zhang, H.; Driver, L.C.; Wendelschafer-Crabb, G.; Kennedy, W.R.; Dougherty, P.M. Follow-up psychophysical studies in bortezomib-related chemoneuropathy patients. J. Pain 2011, 12, 1017-1024. [CrossRef] [PubMed]

39. Maggioni, D.; Nicolini, G.; Chiorazzi, A.; Meregalli, C.; Cavaletti, G.; Tredici, G. Different effects of erythropoietin in cisplatinand docetaxel-induced neurotoxicity: An in vitro study. J. Neurosci. Res. 2010, 88, 3171-3179. [CrossRef]

40. Malgrange, B.; Delree, P.; Rigo, J.M.; Baron, H.; Moonen, G. Image analysis of neuritic regeneration by adult rat dorsal root ganglion neurons in culture: Quantification of the neurotoxicity of anticancer agents and of its prevention by nerve growth factor or basic fibroblast growth factor but not brain-derived neurotrophic factor or neurotrophin-3. J. Neurosci. Methods 1994, 53, 111-122.

41. Pittman, S.K.; Gracias, N.G.; Fehrenbacher, J.C. Nerve growth factor alters microtubule targeting agent-induced neurotransmitter release but not MTA-induced neurite retraction in sensory neurons. Exp. Neurol. 2016, 279, 104-115. [CrossRef]

42. Ta, L.E.; Espeset, L.; Podratz, J.; Windebank, A.J. Neurotoxicity of oxaliplatin and cisplatin for dorsal root ganglion neurons correlates with platinum-DNA binding. NeuroToxicology 2006, 27, 992-1002. [CrossRef] 
43. Wang, D.; Hara, R.; Singh, G.; Sancar, A.; Lippard, S.J. Nucleotide excision repair from site-specifically platinum-modified nucleosomes. Biochemistry 2003, 42, 6747-6753. [CrossRef]

44. Clayton, D.A.; Doda, J.N.; Friedberg, E.C. The absence of a pyrimidine dimer repair mechanism in mammalian mitochondria. Proc. Natl. Acad. Sci. USA 1974, 71, 2777-2781. [CrossRef]

45. Kazak, L.; Reyes, A.; Holt, I.J. Minimizing the damage: Repair pathways keep mitochondrial DNA intact. Nat. Rev. Mol. Cell Biol. 2012, 13, 659-671. [CrossRef]

46. Kondoh, H.; Lleonart, M.E.; Gil, J.; Wang, J.; Degan, P.; Peters, G.; Martinez, D.; Carnero, A.; Beach, D. Glycolytic enzymes can modulate cellular life span. Cancer Res. 2005, 65, 177-185.

47. Maj, M.A.; Ma, J.; Krukowski, K.N.; Kavelaars, A.; Heijnen, C.J. Inhibition of Mitochondrial p53 Accumulation by PFT-mu Prevents Cisplatin-Induced Peripheral Neuropathy. Front. Mol. Neurosci. 2017, 10, 108. [CrossRef]

48. Marullo, R.; Werner, E.; Degtyareva, N.; Moore, B.; Altavilla, G.; Ramalingam, S.S.; Doetsch, P.W. Cisplatin induces a mitochondrialROS response that contributes to cytotoxicity depending on mitochondrial redox status and bioenergetic functions. PLoS ONE 2013, 8, e81162. [CrossRef]

49. Preston, T.J.; Henderson, J.T.; McCallum, G.P.; Wells, P.G. Base excision repair of reactive oxygen species-initiated 7,8-dihydro-8oxo-2'-deoxyguanosine inhibits the cytotoxicity of platinum anticancer drugs. Mol. Cancer 2009, 8, 2015-2026. [CrossRef]

50. Allgayer, J.; Kitsera, N.; von der Lippen, C.; Epe, B.; Khobta, A. Modulation of base excision repair of 8-oxoguanine by the nucleotide sequence. Nucleic Acids Res. 2013, 41, 8559-8571. [CrossRef]

51. Pan, L.; Zhu, B.; Hao, W.; Zeng, X.; Vlahopoulos, S.A.; Hazra, T.K.; Hegde, M.L.; Radak, Z.; Bacsi, A.; Brasier, A.R.; et al. Oxidized Guanine Base Lesions Function in 8-Oxoguanine DNA Glycosylase-1-mediated Epigenetic Regulation of Nuclear Factor kappaB-driven Gene Expression. J. Biol. Chem. 2016, 291, 25553-25566. [CrossRef] [PubMed]

52. Boldogh, I.; Hajas, G.; Aguilera-Aguirre, L.; Hegde, M.L.; Radak, Z.; Bacsi, A.; Sur, S.; Hazra, T.K.; Mitra, S. Activation of ras signaling pathway by 8-oxoguanine DNA glycosylase bound to its excision product, 8-oxoguanine. J. Biol. Chem. 2012, 287, 20769-20773. [CrossRef] [PubMed]

53. Luo, J.; Hosoki, K.; Bacsi, A.; Radak, Z.; Hegde, M.L.; Sur, S.; Hazra, T.K.; Brasier, A.R.; Ba, X.; Boldogh, I. 8-Oxoguanine DNA glycosylase-1-mediated DNA repair is associated with Rho GTPase activation and alpha-smooth muscle actin polymerization. Free Radic. Biol. Med. 2014, 73, 430-438. [CrossRef]

54. Varshney, D.; Spiegel, J.; Zyner, K.; Tannahill, D.; Balasubramanian, S. The regulation and functions of DNA and RNA Gquadruplexes. Nat. Rev. Mol. Cell. Biol. 2020, 21, 459-474. [CrossRef] [PubMed]

55. Fleming, A.M.; Zhu, J.; Jara-Espejo, M.; Burrows, C.J. Cruciform DNA Sequences in Gene Promoters Can Impact Transcription upon Oxidative Modification of 2'-Deoxyguanosine. Biochemistry 2020, 59, 2616-2626. [CrossRef]

56. Kim, N. The Interplay between G-quadruplex and Transcription. Curr. Med. Chem. 2019, 26, 2898-2917. [CrossRef]

57. Mijit, M.; Caston, R.; Gampala, S.; Fishel, M.L.; Fehrenbacher, J.; Kelley, M.R. APE1/Ref-1—One Target with Multiple Indications: Emerging Aspects and New Directions. J. Cell Signal. 2021, 2, 151-161.

58. Malfatti, M.C.; Antoniali, G.; Codrich, M.; Tell, G. Coping with RNA damage with a focus on APE1, a BER enzyme at the crossroad between DNA damage repair and RNA processing/decay. DNA Repair 2021, 104, 103133. [CrossRef]

59. Tosolini, D.; Antoniali, G.; Dalla, E.; Tell, G. Role of phase partitioning in coordinating DNA damage response: Focus on the Apurinic Apyrimidinic Endonuclease 1 interactome. Biomol. Concepts 2020, 11, 209-220. [CrossRef]

60. Kelley, M.R.; Wikel, J.H.; Guo, C.; Pollok, K.E.; Bailey, B.J.; Wireman, R.; Fishel, M.L.; Vasko, M.R. Identification and Characterization of New Chemical Entities Targeting Apurinic/Apyrimidinic Endonuclease 1 for the Prevention of Chemotherapy-Induced Peripheral Neuropathy. J. Pharm. Exp. 2016, 359, 300-309. [CrossRef]

61. Sidorenko, V.S.; Nevinsky, G.A.; Zharkov, D.O. Specificity of stimulation of human 8-oxoguanine-DNA glycosylase by AP endonuclease. Biochem. Biophys. Res. Commun. 2008, 368, 175-179. [CrossRef]

62. Hill, J.W.; Hazra, T.K.; Izumi, T.; Mitra, S. Stimulation of human 8-oxoguanine-DNA glycosylase by AP-endonuclease: Potential coordination of the initial steps in base excision repair. Nucleic Acids Res. 2001, 29, 430-438. [CrossRef]

63. Kothandapani, A.; Dangeti, V.S.; Brown, A.R.; Banze, L.A.; Wang, X.H.; Sobol, R.W.; Patrick, S.M. Novel role of base excision repair in mediating cisplatin cytotoxicity. J. Biol. Chem. 2011, 286, 14564-14574. [CrossRef]

64. Limpose, K.L.; Corbett, A.H.; Doetsch, P.W. BERing the burden of damage: Pathway crosstalk and posttranslational modification of base excision repair proteins regulate DNA damage management. DNA Repair 2017, 56, 51-64. [CrossRef]

65. Kothandapani, A.; Sawant, A.; Dangeti, V.S.; Sobol, R.W.; Patrick, S.M. Epistatic role of base excision repair and mismatch repair pathways in mediating cisplatin cytotoxicity. Nucleic Acids Res. 2013, 41, 7332-7343. [CrossRef]

66. Wong, H.K.; Muftuoglu, M.; Beck, G.; Imam, S.Z.; Bohr, V.A.; Wilson, D.M., 3rd. Cockayne syndrome B protein stimulates apurinic endonuclease 1 activity and protects against agents that introduce base excision repair intermediates. Nucleic Acids Res. 2007, 35, 4103-4113. [CrossRef]

67. Boukelmoune, N.; Laumet, G.; Tang, Y.; Ma, J.; Mahant, I.; Singh, S.K.; Nijboer, C.; Benders, M.; Kavelaars, A.; Heijnen, C.J. Nasal administration of mesenchymal stem cells reverses chemotherapy-induced peripheral neuropathy in mice. Brain Behav. Immun. 2021, 93, 43-54. [CrossRef]

68. Tan, D.; Zhang, H.; Deng, J.; Liu, J.; Wen, J.; Li, L.; Wang, X.; Pan, M.; Hu, X.; Guo, J. RhoA-GTPase Modulates Neurite Outgrowth by Regulating the Expression of Spastin and p60-Katanin. Cells 2020, 9, 230. [CrossRef] 
69. Calls, A.; Torres-Espin, A.; Navarro, X.; Yuste, V.J.; Udina, E.; Bruna, J. Cisplatin-induced peripheral neuropathy is associated with neuronal senescence-like response. Neuro-Oncology 2021, 23, 88-99. [CrossRef]

70. Acklin, S.; Zhang, M.; Du, W.; Zhao, X.; Plotkin, M.; Chang, J.; Campisi, J.; Zhou, D.; Xia, F. Depletion of senescent-like neuronal cells alleviates cisplatin-induced peripheral neuropathy in mice. Sci. Rep. 2020, 10, 14170. [CrossRef]

71. Sikora, E.; Bielak-Zmijewska, A.; Dudkowska, M.; Krzystyniak, A.; Mosieniak, G.; Wesierska, M.; Wlodarczyk, J. Cellular Senescence in Brain Aging. Front. Aging Neurosci. 2021, 13, 646924. [CrossRef] [PubMed]

72. Coppe, J.P.; Desprez, P.Y.; Krtolica, A.; Campisi, J. The senescence-associated secretory phenotype: The dark side of tumor suppression. Annu. Rev. Pathol. 2010, 5, 99-118. [CrossRef] [PubMed]

73. Li, M.; Yang, X.; Lu, X.; Dai, N.; Zhang, S.; Cheng, Y.; Zhang, L.; Yang, Y.; Liu, Y.; Yang, Z.; et al. APE1 deficiency promotes cellular senescence and premature aging features. Nucleic Acids Res. 2018, 46, 5664-5677. [CrossRef] [PubMed]

74. Hanna, B.M.F.; Helleday, T.; Mortusewicz, O. OGG1 Inhibitor TH5487 Alters OGG1 Chromatin Dynamics and Prevents Incisions. Biomolecules 2020, 10, 1483. [CrossRef]

75. Rai, G.; Vyjayanti, V.N.; Dorjsuren, D.; Simeonov, A.; Jadhav, A.; Wilson, D.M., 3rd; Maloney, D.J. Synthesis, biological evaluation, and structure-activity relationships of a novel class of apurinic/apyrimidinic endonuclease 1 inhibitors. J. Med. Chem. 2012, 55, 3101-3112. [CrossRef]

76. Schindelin, J.; Arganda-Carreras, I.; Frise, E.; Kaynig, V.; Longair, M.; Pietzsch, T.; Preibisch, S.; Rueden, C.; Saalfeld, S.; Schmid, B.; et al. Fiji: An open-source platform for biological-image analysis. Nat. Methods 2012, 9, 676-682. [CrossRef] 